\section{(2) OPEN ACCESS}

\title{
'Look under the sheets!' Fighting with the senses in relation to defecation and bodily care in hospitals and care institutions
}

\author{
Sjaak van der Geest $\bullet$, ' Shahaduz Zaman²
}

\begin{abstract}
${ }^{1}$ Faculty of Social and Behavioural Sciences, University of Amsterdam, Amsterdam, The Netherlands

${ }^{2}$ Brighton, UK
\end{abstract}

\section{Correspondence to}

Professor Sjaak van der Geest, Faculty of Social and Behavioural Sciences, University of Amsterdam, Amsterdam 1012 $D L$, The Netherlands; s.vandergeest@uva.n

Accepted 31 March 2020 Published Online First 30 June 2020
Check for updates

(C) Author(s) (or their employer(s)) 2021. Re-use permitted under CC BY-NC. No commercial re-use. See rights and permissions. Published by BMJ.

To cite: van der Geest S, Zaman S. Med Humanit 2021:47:103-111.

\section{ABSTRACT}

This essay focuses on sensory aspects of care in situations surrounding defecation in hospitals and other care institutions. Sensory activity does not merely encompass pleasant experiences that enhance healing and well-being. Anthropologists - and other disciplines as well-have paid little attention to unpleasant and disgusting experiences that our senses meet and that may rather increase pain and suffering in the context of care. Our essay therefore reflects on a common but highly uncomfortable aspect of being a-sometimes bedridden-patient: defecation. The sensory effects of human defecation are well known. They affect at least four of the five traditional senses. But equally repulsive are the social and emotional effects that defecation in a hospital context has on both patients and professional and other care providers. The essay is based on anthropological observations and the authors' personal experiences in Bangladesh, Ghana and the Netherlands and covers a wide variety of cultural and politicoeconomic conditions. It further draws on (scarce) scientific publications as well as on fictional sources. Extensive quotations from these various sources are presented to convey the lived sensorial experience of disgust and overcoming disgust more directly to the reader.

\section{INTRODUCTION}

This essay evolved from a paper presented at a conference on the 'Aesthetics of healing: Working with the senses in therapeutic contexts' which was held at the University of Münster, Germany in May 2019. Our intention was to draw attention to the unaesthetic sensory aspects of care and thereby to counterbalance the somewhat idyllic assumptions in the conference theme. The subtitle 'Working with the senses' was thus changed to 'Fighting with the senses'.

The senses received relatively little attention during the early beginnings of medical anthropology, but this should not be interpreted as a sign of a lack of awareness of their presence in human behaviour, particularly in settings of sickness, suffering, healing and care. No one will in earnest deny or depreciate the huge impact of sensorial experience on our lives and on experiences of illness and suffering in particular. ${ }^{12}$ Grasping sensorial modalities in words and arguments, however, proved a huge challenge to anthropologists struggling with the 'mindful body', which delayed theoretical and methodological analysis of their observations.
In this essay we will skip a discussion of the long process of growing anthropological attention for and exploration of sensorial perception and its accompanying emotions. Instead we will move straight to one particular emotion that involves a wide array of sensory modules and reactions, the five conventional senses in Western psychology, as well as the 10 or more that have been reported in observations in other cultures. ${ }^{3}$ This emotion is disgust.

There is no rigid methodology for this essay as may be required in medical or sociological studies. Part of the data are based on anthropological participant observation in Ghana and Bangladesh about which the authors have published before. Part also derive from self-reflective introspection and the authors' personal experiences in Bangladesh, Ghana and the Netherlands. We further draw on scientific publications by other authors as well as fictional sources. Finally, some descriptions were taken from narratives by friends and colleagues in informal conversations. They approved of quoting their experiences anonymously. Nijhof's communication has not been anonymised with his permission. He had before written about his use of stoma material in his autobiographic essay Sickness Work. ${ }^{4}$

\section{DISGUST: A NEGATIVE EMOTION}

The intensity of disgust that takes possession of the entire body and causes uncontrollable corporeal reactions such as extreme facial expressions and visceral nausea has long fascinated students from various disciplines. The search for the ultimate disgust sensation has produced a large variety of different-sometimes conflicting, sometimes complementary-hypotheses.

In 1927, Aurel Kolnai, an Austrian philosopher and phenomenologist, produced one of the first scholarly studies of disgust, which was republished in English in 2004 with an introduction by Carolyn Korsmeyer and Barry Smith. Kolnai lists nine material sources of disgust: putrefaction, excrement, bodily secretions, dirt, certain animals (especially insects), certain foods, human bodies, 'exaggerated' fertility, disease and deformation. How and why these 'objects' cause revulsion is harder to pin down, however. Korsmeyer and Smith write that for Kolnai:

Objects of material disgust share the impression of life gone bad, of flesh turning towards death, and of a primordial and profuse degeneration of life from the muck of decaying organic matter. Things that rot and 
putrefy become the fuel for maggots and bacteria; insects in swarms give the impression of excessive, mindless generation, of life "senseless, formless, surging" (p16). ${ }^{5}$

It would not be fair to say that Kolnai only looked at material objects that cause disgust. He also included contextual circumstances and sociocultural interpretations, as Korsmeyer and Smith point out. Yet, having said this, it is also true that Kolnai and many scholars after him focused mainly on concrete material things and beings that lead to disgust because of what they are. As a result, attempts to explain what disgust is and does remained rather static and tended to fall victim to circular reasoning: disgust is caused by disgusting things.

Evolutionist scholars largely followed this material perspective, which still constitutes a dominant vision in psychology, but added a medical reason. ${ }^{6-9}$ They look on the fear and avoidance of dirt as a defence mechanism against sickness and other dangers, and postulate a hidden rationality in the seemingly spontaneous disgust with dirty things and animals. Religious rules about purity and pollution and taboos on eating certain foods or touching unclean objects or persons are seen as medical prescriptions in disguise. Mosaic laws in the biblical texts of Deuteronomy and Leviticus, for example, are perceived as rules for healthy living, even though some of these rules do not make any medical sense today. The following things are najis (impure) in Islam: wine and other alcoholic drinks, dogs, swine, dead animals that were not ritually slaughtered, blood, excrement, and the milk of animals whose meat Muslims are not allowed to eat. ${ }^{10}$ Disgust 'is one of the mechanisms crafted by natural selection to keep our distance from contagion' (p22). ${ }^{8}$ Faeces, for example, is mentioned as a transmitter of more than 20 diseases. Other people's breath, lice and rats, and sexual organs, all of which score highly for human disgust, are also common sources of infection.

It was against these evolutionist and materialist interpretations of dirt avoidance that Mary Douglas took a stand. 'In chasing dirt', she wrote, 'we are not governed by anxiety to escape disease, but are positively re-ordering our environment, making it conform to an idea' (p12). ${ }^{11}$ With her famous dictum 'Dirt is matter out of place', she rejected the concept of dirt as a fixed quality of particular objects, substances, animals or human beings and turned dirt into a radically contextual phenomenon. Absolute dirt, therefore, does not exist; it is the context that determines what/who is clean and what/who is dirty. Saliva in my mouth or caught in a handkerchief is hygienic, but when it falls on the table it is extremely dirty. Conversely, something that is generally regarded as pure, a glass of wine, becomes dirt when it is spilled on a dress. Douglas's thesis is that the concepts of dirt and cleanliness are strong tools to establish order. They point out what is the appropriate place for anything in life. Although Douglas did not focus on the disgust emotion, her view on dirt has far-reaching consequences for our understanding of disgust. If 'absolute dirt' does not exist, an absolute definition of what elicits disgust is not possible.

Inspired by Douglas's vision of dirt, one of us has suggested a more relativist understanding of the concept of 'out of place'. Douglas's emphasis on dirt's out-of-place condition was very much tied to the literal (spatial) meaning of 'place'. We want to add a relational dimension to this out-of-place experience. Of course, the strength of the disapproval of matter out of place is linked to the substance of the matter itself, but the place where the object is or the activity that takes place, the manner in which its presence is communicated, and the identity of the actor who is directly associated with the matter or activity all dictate the total experience. ${ }^{12}$ In this essay we focus on this last aspect: whose matter is it? The answer to the question 'whose?' determines the experience of disgust much more than has been suggested by Douglas and all other authors who have written about the cultural meaning of, for example, defecation and faeces. By adding a sociological dimension, we hope to make Douglas's theory of matter out of place more true to life and more effective as an interpretative tool (p86). ${ }^{12}$

The strongest feelings of disgust arise in the unwelcome close presence of others, physically or metonymically. Shoes on a table may be dirty, as Douglas writes, but their presence on the table becomes really uncomfortable if they belong to another person with whom we do not want to be intimate in any way. If the shoes are placed right in front of me, they become a disgusting invasion of my personal territory; they penetrate my 'social skin'. The experience of sexual harassment, the unwanted breach of personal and bodily integrity, causes the same revulsion, but far more intensely. What is most deeply felt to be out of place is what invades our most private domain against our will. Apparently, the dominant guarantor of social order (to stay with Douglas), at least in Western society, are the boundaries between individual people. Transgressing these boundaries results in undesired intimacy, which is the ultimate dirt. It is no surprise that sexual harassment is viewed as an extremely disgusting experience and sexual abuse as a hideous crime.

Our suggestion that concerns about personal privacy and integrity constitute the final and most deeply rooted source of disgust does not necessarily reject or disprove the earlier theories mentioned above, but should be added to them to make them more convincing and to produce a more plausible interpretation of sentiments of disgust surrounding defecation in contexts of care.

\section{TWO ETHNOGRAPHIC OBSERVATIONS}

In 1999 the first author was admitted with cholera to a Ghanaian hospital and put on a drip. Here are a few observations from his diary.

Friday. In the middle of the night I wake up, my guts are about to explode. I climb out of bed, take my drip and start looking for a nurse. I leave a trail of greyish drops behind me. No nurse to be seen. I am distraught, where is the toilet? One of my roommates wakes up and shows me the way: there, behind that door... I flinch when I reach the place. The stench hits me in the face, the floor is flooded. Many sorts of substances are floating in the toilet bowl and a rusty bucket is filled with used toilet paper. Flies are buzzing in and around the bucket. But there is no time for hesitation. With a sigh of relief I let the rest of my cargo plop into the darkness down... That will happen about twenty times, shuffling toward the door, always with one hand holding the IV standard on wheels, in the other hand my dwindling roll of toilet paper.

Saturday. What strikes me is that the doctors and nurses are immaculately dressed, especially the female doctors walking around as if they participate in a fashion show; no white coats but richly coloured robes and hung with gold jewellery. Do they know the sordid world behind that one door? They'll never go there, I'm sure of that. They ask me: "What does your stool look like?" How do I know; in that dark cell one can hardly recognize anything. And how should I distinguish what is mine and what my predecessors'?

Reflecting on this experience, after being discharged some weeks later, he wrote:

My most intense experience was undoubtedly the confrontation with the 'backstage' of the hospital: the broken toilet, the flooded floor, the flies in the open bucket with used toilet paper - a source of infection in what should be a paragon of hygiene. The contrast between 
the medical rules and the sanitary reality was overwhelming. A second contrast - between the stylish appearance of the doctor and the disgusting filth of the toilet and its surroundings - may provide the key to the explanation of this contradiction. For doctors and nurses what was behind that door was an unknown world, or rather a world they did not want to know. In a society where health facilities are limited and defective, avoidance and denial are the most efficient way of dealing with the omnipresent dirt, not just by doctors and nurses, but also by policymakers and anyone who can afford it. Rational considerations, based on scientific knowledge about contagion, are easily put aside by emotions of disgust and social discomfort. What one cannot resolve in the everyday reality of the hospital, one resolves by not thinking about it; an exercise in mental hygiene.

In 2002, the second author carried out anthropological research in a large public hospital in his home country of Bangladesh. He took special interest in the daily mundane things of hospital life, including defecation and the use of toilets. In his hospital ethnography he wrote:

Most of the patients told me that during their stay at hospital, their most horrible experience was going to the toilets. Each day, more than one hundred patients and all of their relatives use the four toilets. During the large part of the day there is no running water in the toilet. Many are unfamiliar with how a commode should be used. Moreover, there is a big bin inside the toilet enclosure where the patients put their leftover food and other rubbish [which] attracts the crows... (p64). ${ }^{13}$

Most of the patients in the orthopaedic ward are non-ambulatory; their traction or plasters confine them to bed. These patients have to use bedpans for their toilet needs. I observed that when patients defecate into a bedpan, with the assistance of their relatives, the patients usually keep their eyes closed, probably to avoid embarrassment. Bed curtains are not provided. One patient told me: "See, what punishment Allah has given me, now I have to defecate in front of so many people" (p92). ${ }^{13}$

To avoid such a state, most patients try to delay defecation as long as possible. A number of patients defecate only once in two or three days. One patient did not go to the toilet until five days after admission. I found that a strategy patients use to avoid needing the toilet is to avoid food completely, or to just eat very little... Public defecation and urination are not uncommon in Bangladesh. It is not unusual to see people in rural areas defecating on the bank of the river, in the city slum areas or along the side of the railway lines. However, defecating inside a hospital ward, surrounded so closely by other people, is experienced as excruciatingly embarrassing by patients (p93). ${ }^{13}$

Informal payment begins upon entry to the hospital. The liftman demands money for taking the patients to their respective wards, the ward boy demands money for bringing the patients from the outdoor patient's consultation room to the ward, ... and cleaners demand money in exchange for helping the patient to go to the toilet in the absence of his or her relatives (p87). ${ }^{13}$

These ethnographic observations in two non-Western countries contain references to four main categories of actors involved in the emotional challenges that are brought about by defecation in the setting of hospitals and other care institutions. The first category are the patients, who suffer the anxiety of having to relieve themselves in extremely uncomfortable circumstances, such as awkward bedpans, dirty toilets and with a lack of privacy. Next are patients' family members, who in certain hospitals are expected to deliver bodily care to their hospitalised relatives. Nurses are the third category. In most societies they are the professionals in charge of hygiene on the ward and whose task is to provide bodily care to patients. But, as we will see, in various societies they have delegated this unpleasant and 'dirty' task to relatives. Being overburdened with other tasks, due to shortage of nursing staff, may be an additional reason to leave the bodily care to relatives and lower staff members. Finally there are the cleaners and other low-ranked workers, who are responsible for keeping the ward and sanitary facilities clean and who may also get involved in helping patients go to the toilet as well as cleaning them. Unsurprisingly, doctors, who are not involved in bodily care, remain out of the picture.

\section{PATIENT ANXIETIES}

For hospital patients there are two ways of relieving themselves: going to the toilet (whether accompanied by someone or not) or defecating on the ward, using a bedpan in the bed or a toilet chair ('commode') next to the bed.

The first option can be unpleasant and frightening if the facility is filthy, as described in the above observations by the two authors. Such conditions are fairly common in hospitals in lowincome societies that struggle with shortages of money and qualified personnel, as well as with overcrowding, bad management and corruption. For another example, see Tantchou's description in a Cameroonian hospital:

I am at the maternity ward, which has received a new chamber pot. It is stainless steel, disinfects more easily than the previous ones, which were plastic. In the delivery room, two women are waiting. One of them asks for the chamber pot. Meanwhile, the other woman is examined. A few minutes later, the woman who asked for the pot calls for it to be removed. Her companion comes to collect it. The sink in the treatment room is clogged. She nevertheless empties the pot, rinses it and brings it back. Another woman comes to ask for the pot. The midwives find traces of faeces and point it out to the previous patient. Her companion rinses it again and brings it back. Finally, a midwife asks her to leave the pot in the "workroom" because "soon you will still need it". I ask if there are no toilets; a nurse answers me: no. One trainee says there are toilets, but they are locked (p165; our translation from French in italics). ${ }^{14}$

\section{Another Bangladeshi anthropologist wrote to us:}

One of the things that struck me (and it strikes anyone in fact in a public hospital) is the amount of human faeces, urine, and other bodily discharge (used period pads/cloths) that are in various parts of the vicinity, especially the pathways between the different hospital buildings, or the back of certain buildings which had turned into open garbage dumps. (S Siddiqui, personal communication, 18 March 2019)

The faecal dirt found outside of the hospital is of course an indication of the lack of access to proper toilet facilities inside, for patients and their visitors.

But also in high-income countries, complaints about dirty hospital toilets are not uncommon, although we should take into account that perceptions and standards of dirty versus clean may vary considerably. An article in British's The Guardian reported:

Toilets and bathrooms in NHS [National Health Service] hospitals have become dirtier over the past year, according to a nationwide survey of patients. The report casts doubt on the government's claims that hospitals are becoming cleaner.... Hospitals in and around London appeared to have a particularly low satisfaction rating on hygiene. Kingston Hospital in Surrey comes out worst, with 38 per cent of patients saying they thought the washing facilities were 'not very, or not at all clean'. Specialist hospitals with fewer patients had the highest ratings.... ${ }^{15}$

Having to relieve oneself on the ward, in the presence of other patients and a nurse or a relative, is much more uncomfortable, however, than coping with a dirty toilet. The decisive difference 
is the lack of privacy during an action that is undertaken in the utmost privacy when observed in normal daily life. This lack of privacy may be more likely to occur in a poorly equipped hospital in the 'South' with more patients in the room and less physical privacy protection, but the experience of being exposed and deprived of privacy is probably similar in 'Western' contexts.

The bedridden patients in the author's research reduced their intake of food to prevent the painful experience of defecating 'in public', but in Dutch hospitals the unease is no less. An acquaintance (MZ) wrote to us:

My experiences with a bedpan in the hospital are limited. I always went straight to the toilet as soon as I was disconnected from the tubes and other devices. Twice I did have a humiliating experience however when I had caught a strange bacillus and could not leave the bed. The nursing staff did not come quickly with a large pot, but brought a small one. I could barely sit on it. The droppings leaked on all sides. Awful smell. I was ashamed to death. Shitting is an autonomous process and must be kept in your own hands.

In a follow-up message he added:

There are always multiple feelings when you burden others with the slurry and stench of excrements. Shame, you feel abandoned and humiliated by your body, you have no control, and because of your own bad condition you bother others to clean up the mess. I once stood next to my bed, trembling clinging to an infusion stand, apologising extensively to a young nurse and offering to help make the bed. She laughed, did not thank me for my offer and said it was part of her job. What had happened was normal in the given situation. You are thus confronted with a new normal, you have to adapt to a different reality. It might have been preventable because the nurse had not reacted on my call a few times because of other concerns. But that too was part of the new normal. (MZ, personal communication, March 2019)

A close friend and retired nurse reacted to this story by stating that she could have been that nurse. She had done this so often: throwing clean towels or sheets over filthy accidents without any hesitation. If it happened in bed, first, headrest down (so that the patient could not see it), then a large double towel over 'the disaster', and then quietly fixing things out of sight of the patient, to prevent the patient from feeling ashamed and uncomfortable. 'This should be a normal and automatic action for every nurse', a matter of professionalism (cf Käthe Von Bose, pp155-159). ${ }^{16}$

Gerhard Nijhof, a medical sociologist who wrote about his experiences as a patient with cancer in a Dutch hospital and about his recovery at home, ${ }^{4}$ wrote to us:

I have some experience with emptying my stoma bag in bed at the hospital. That is much easier for me than pooping in bed; probably because the bag is in-between. Makes it more of a technical enterprise. My reaction also depends on the reaction of bystanders, nurses usually in the hospital. I remember one of the first days with a stoma. You do not yet have a feeling of 'full'. I stood up and the whole bag flew off. A large puddle on the floor. Without saying anything, a nurse grabbed two towels and brushed things up. Within a minute it was as if nothing had happened. 'Undoing', you could say.

The situation becomes more dramatic when a patient is incontinent. A good and regular bowel movement is a sign of physical health and indicates psychological and social well-being. The regularity of bowel movements, metaphorically and metonymically, represents the regularity of a person's life in a general sense. Pooping well symbolises control, as Rachel Lea writes. ${ }^{17}$ Children are taught to become potty-trained as quickly as possible. Dutch culture is preoccupied with potty training. Not being toilet-trained is a serious threat to one's social and psychological position. Those who are not are either not yet or are no longer complete human beings. Having no bowel control implies a painful form of dependence. Independence and privacy must be sacrificed in daily functioning. This dependency, a patient with paraplegia said in a television interview, is worse than being unable to walk.

It is not surprising that the industry has developed many tools to reduce the inconvenience of incontinence and other problems related to urine and faeces. These means, such as catheters, stoma bags, special diapers and toilet aids, primarily reduce the inconvenience for the person involved, but also alleviate the work of caregivers. For caregivers in the home situation, the incontinence of a relative can become the 'breaking point', the moment when they think they can no longer cope with their duties as a caregiver.

In a health institution or nursing home, staff are supposed to have a professional attitude towards faeces and defecating patients, meaning that they learn to deal with it neutrally, so that the patient or resident does not feel that his private self is being violated. However, this often does not work. Admitting a doctor to the most intimate parts of the body is apparently less painful (more technical and therefore more neutral) than having to accept help from and the presence of other persons when 'accidents' happen.

During her research in a British hospice, Julia Lawton observed that bodily deterioration leading to continuous incontinence and extreme sensorial embarrassment became a breaking point for several patients. They asked to be isolated and withdrew into themselves. Perceiving themselves as a source of repetitive disgust resulted in the wish to disappear completely and be freed from the shame of having turned into a dirty 'object'. Describing the case of a woman with the fictitious name of Deborah, Lawton writes:

When Deborah's bodily deterioration escalated, I observed that she had suddenly become a lot more withdrawn. After she had been on the ward for a couple of days she started asking for the curtains to be drawn around her bed to give her more privacy. A day or so later she stopped talking altogether, unless it was really necessary (to ask for the commode, for example), even when her family and other visitors were present. Deborah spent the remaining ten days of her life either sleeping or staring blankly into space. She refused all food and drink... She [had] shut herself off in a frustrated and irreversible silence. Deborah was moved back into a side room and died there a couple of days later (p129). ${ }^{18}$

\section{HELPING RELATIVES}

Zaman observed that most patients on the orthopaedic ward in the Bangladeshi hospital had a relative with them who helped them in various ways. ${ }^{13}, 19$ Orthopaedic patients are generally bedridden, with plaster casts on their hands or legs, so they are very dependent on their attendants to take care of their bodily needs, such as going to the toilet or feeding and bathing. Although the nurses are supposed to do these jobs, Bangladeshi nurses hardly do any nursing in hospitals and are mostly engaged in administrative work. Without relatives, the ward would not be able to function, even though the nurses and doctors repeatedly complain that the relatives are a nuisance. Bangladesh is not unique in this. Worldwide in low-income countries, hospitals depend on family members who do most of the bodily care for patients, in particular the 'dirty work' that nurses do not like or are unwilling to do. Alice Street, who carried out research in a Papua New Guinea public hospital, wrote that: 
Due to a lack of nursing manpower in the Papua New Guinea health system, patients are expected to bring a 'wasman' with them to the hospital; a family member who is able to care for the patient, accompany them to the toilet, wash them, and collect their food from the hospital kitchen at meal times. The wasman, often a child, a wife or a sister, will usually sleep underneath the patient's bed.... Very occasionally a cloth screen is drawn around a bed when the doctor needs to conduct an intimate examination, or when a wasman is unable to transport a patient to the toilet (p196). ${ }^{20}$

Hannah Brown observed the same phenomenon in Kagot hospital in Kenya. Almost all patients had someone caring for them full time, and patients without caregivers were said to be 'abandoned by their relatives'. Caregivers were almost always female relatives. Wives or mothers were the ideal carers for men. Mothers, sisters, and for older women, daughters, were the preferred carers for women. Brown describes their activities as follows:

Caregivers washed, dressed, and fed their patients and helped them to the toilet if they could walk to the pit latrines outside, or lifted a leso, a piece of multipurpose cloth, so their patient could squat behind it over a plastic basin. Some drugs were kept in the ward, but caregivers were frequently sent to buy medicines and medical equipment such as intravenous giving sets from the hospital pharmacy where they sold drugs at discounted prices, or from the better stocked private pharmacies in the town center. If the doctor ordered an X-ray, usually to check for tuberculosis, it was the caregiver's responsibility to find the wheelchair, lift the patient out of bed, and wheel them to the X-ray room. It was also the responsibility of the caregiver to find money to pay for these items (p24). ${ }^{21}$

In another Kenyan hospital, however, the staff were more strict in terms of allowing relatives on the ward:

They allowed some relatives to stay longer to assist weak bedridden patients. However, they could not stay during procedures or in the night after 9:00 pm. Hospital staff tended to hang back during 'patients' time with their visitors. ...Immediate family members helped patients with feeding, the toilet, and general hygiene. They brought changes of clothes and took away dirty ones for washing. Relatives and friends played an important role of connecting inpatients to experiences outside the ward. They supplied alternative medicines, homemade food, and patented food supplements. Patients' visitors also ran errands for them, such as buying snacks, newspapers, and mobile telephone airtime (p97). ${ }^{22}$

Although the recruitment of relatives as caregivers in hospitals is usually regarded as a shortcoming of the hospital, Chang discusses the involvement of relatives in Taiwanese hospitals as a possible step towards improving the quality of care. Nevertheless, according to the author, this policy entails a hidden strategy to transmit the costs and burdens of care onto Taiwanese families, who may be unable to carry that burden. ${ }^{23}$

Nowhere in the literature on relatives as hospital assistants did we read anything about the emotional impact on both the patient and the relative of the latter's assistance during defecation by the patient. It seems plausible that patients would prefer to receive intimate bodily care from a close relative rather than from a professional stranger. But it is equally plausible that patients would prefer a neutral outsider, a nurse, with whom they do not have a personal relationship that may be tied up with taboos and feelings of mutual unease and shame, if not disgust. In fact, close relatives may be more undesired invaders of one's privacy than unknown strangers. We looked in vain for researchers who explored such feelings of mutual shame and discomfort in care activities between relatives, and have based the above statement mainly on observations and conversations in our own environments. One author who discussed in more general terms why patients or dependent elderly people prefer outsiders to relatives when it comes to care activities is Klaas Van der Veen. ${ }^{24} \mathrm{He}$ has argued that it is understandable that older people (in the Netherlands) who want to maintain a good relationship with their children are keen to avoid receiving material care from them, ranging from cleaning the house to bodily care. They prefer to receive daily care from professionals who are paid for their work and with whom they do not have obligations of long-term reciprocity and dependency (p62). ${ }^{24}$

\section{NURSES: 'ANGELS' OR DEFEATISTS}

After a long period of neglect, nurses have been 'discovered' by social scientists as pivotal actors in healthcare. Nursing studies are now a fast-growing field in medical anthropology. Nursing also takes central stage when we explore emotions and disgust in hospital care. Yet, when it comes to 'dirty work' such as helping patients to defecate, researchers remain silent; they themselves seem to run away in disgust. ${ }^{14,16}$ When Käthe Von Bose witnessed the mess of a patient during the morning round, she was more concerned about her own emotional reaction than with the situation and the encounter between the nurse and the patient (p156). ${ }^{16}$ Lory Jervis remarked:

While pollution is a 'conventional' topic in cultural anthropology, the field as a whole has directed little attention to elimination behaviour [note the civilised terminology].... Even in the ethnographic literature on nursing homes, elimination is apparently a taboo subject. Discussion of incontinence, if it occurs at all, is generally confined to passing references that dramatize the suboptimal state of life and work in these facilities (p86). ${ }^{25}$

But there are laudable exceptions. The most extensive and impressive description we found of the 'dirty work' carried out by nurses is by Julia Lawton, who we cited before. She writes about a woman with the pseudonym of Annie in a hospice in southern England. Annie had cancer and in addition developed a rectovaginal fistula, which meant that her urine and faeces started coming out through the same passageway. Here is a lengthy quotation from her graphic ethnographic observations:

Initially, she [Annie] was sufficiently mobile to take herself independently to the toilet and bathroom, and she remained stubbornly 'selfcaring' even though she had to spend up to onehour cleaning herself up after using the toilet.... About ten days into her admission, Annie deteriorated further. Her fistula enlarged substantially and, as a result, every time she attempted to get out of bed and stand up, diarrhoea would pour straight out of her body. Consequently, Annie had to start using a commode on the ward rather than walking to the toilet.... It was around this time that Annie's bodily degradation began to have a significant impact upon the hospice as a whole. Whenever she used the commode on the ward, the smell would penetrate right through the building to the main entrance. The staff burnt aromatherapy oils around her bed, but, generally, these did little to mask the odour. The other patients complained that sometimes the smell made them want to vomit. Annie became increasingly anxious about the possibility of being discharged home. She felt that she had lost all her dignity. She also stressed that there would be insufficient privacy at home to mask the smell and her degradation from her family. At the multi-disciplinary team meeting to discuss her case, the Senior Consultant argued that it would be 'cruel and futile' to press for a discharge. None of the other staff members challenged his decision in spite of the economic pressures to free Annie's bed. There was no further talk of discharge and Annie and her family were promised that she could remain in the hospice until she died. 
Throughout April, Annie continued to deteriorate. She "rotted away below" (as the nurses put it) and lost all control over her bowel and bladder functions. As a consequence, she suffered from continuous bouts of incontinence. It proved impossible to keep her clean and her sheets fresh. On several occasions when the nurses came to attend to her they found her covered to her shoulders in her own urine and excreta $(\mathrm{p} 125){ }^{18}$

This sad and touching story goes on with a focus on Annie's adamant fight and the problems she caused to the entire hospice and the other patients, but the heroic role of the nurses is almost taken for granted. They supported Annie until the very bitter end, in spite of the unbearable assault on their senses. It is simply part of their work, as the nurse who was cleaning MZ's mess stated (cf the earlier quote from a Dutch hospital).

Johannes Van Dijk describes the case of an elderly man in a care centre for people with dementia in northern Germany, particularly how the nurses tried, and failed, to help him.

Franz Müller (pseudonym), 84 years old, wakes up at 8:00 am, is taken on foot to the toilet by two people, helped with body care and dressing, and then escorted to the living-dining room for breakfast. He eats muesli like at home, and drinks coffee. At home he was then taken to the toilet, because he felt an urge to discharge stimulated by the cereal or coffee. On the toilet then came for several years relatively quickly a "spontaneous well-formed" stool (p23; our translation). ${ }^{26}$

It is not difficult to guess how this story continues. After his breakfast at the care centre, Mr Müller wanted to go to the toilet, but the nurse told him that he had just been there and had to wait a few hours before it was his turn again. He asked again and then a third time to be taken to the toilet, but in vain and he gave up. When it was his turn again, he no longer felt any pressure, and this lasted for 2 days.

Another, somewhat similar, example from a Dutch home for elderly persons with dementia shows how defecation is intertwined not only with daily routines but also with shame.

In the beginning, people with dementia are embarrassed when they are incontinent and when the carers change them. That can also be a reason not to dare to ask where the toilet is, or to say that they don't have to go there. They feel that their dignity is at stake... Later they look for a quiet place to relieve themselves. The carers then find it in a corner of the room, in a bedside table, in a waste basket or in a water glass (p96; our translation). ${ }^{27}$

Nurses often claim that during their training, little or no attention is given to the social and emotional complexities of dealing with dirty substances on the ward. A student nurse in a Ghanaian hospital told Christine Böhmig after giving a patient a bed bath:

I have never before changed diapers, not even with a baby. I did not even know how to open them. Today was my first time of doing such a bath... It is a shock to do it. On all other wards, nobody needed to be assisted in washing. We just learned about all that in the demonstration rooms in our school; our training is very theoretical. I am exhausted (p136). ${ }^{28}$

In another conversation that Böhmig had with some nurses in the same hospital, their ambivalent attitude to bodily care was revealed. One nurse said: "We are not enough so we ask the relatives to wash them. We talk to them and explain all to them. Only the seriously ill ones are exclusively washed by us." But as a senior nurse stated, "Relatives just wash, they don't know what to look for. The patients are under our care. The private parts and oral hygiene, the relatives do not do it, so we have to do it. It is our responsibility.” In reality, Böhmig observed, it was mainly the nursing students and care assistants who were asked to wash bedridden women. This bath could take up to half an hour, especially if the woman was incontinent, had soiled herself and needed to be washed extra carefully (pp135-136). ${ }^{28}$ This 'dirty work' seemed to be relegated to the lower staff.

A retired Dutch nurse criticised her colleagues for avoiding to look under the sheets in order not to be confronted with possible dirt and the unpleasant obligation to clean the patient and change the bedding. An unlucky colleague would then find the mess and would have to do the unpleasant job. Defecation (euphemised as 'def') could thus become a sensitive and divisive issue in team relations among nurses. A Dutch handbook for nurses provides the following instruction on how to deal with human dirt:

When dealing with, for example, the feelings of shame of a patient, the feelings of the nurse play an important role as well.... Everyone, including the patient, finds excretion products dirty. Moreover, the patient finds it very unpleasant to have to saddle someone else with the care of his excretion. It is important that you are aware of your own feelings regarding the excretion of the other.... You will certainly get a question like: "Don't you find this annoying or dirty?" It is unreal to claim that it is fun work or only to answer that "... it is just part of my work". It is also wrong to saddle the patient with a sense of guilt or shame. Show the patient that you understand that he finds it annoying to burden you with chores for his excretion. A remark along the lines of: "It is not the nicest thing in my work, but it is nice that I can help you with this until you can do it yourself again”, seems appropriate and honest (p207; our translation). ${ }^{29}$

This instruction confirms what we mentioned before: it may terribly be embarrassing from a patient's point of view to defecate in a bedpan or-worse-soil the sheets, but nurses 'expect' such accidents from patients with certain conditions, and cleaning them in a neutral and efficient manner is a proof of their professionalism.

An Australian guide for patients provides a list of suggestions for how patients can prepare themselves for the sometimes uncomfortable situation surrounding going to the toilet in a hospital. Below are a few examples:

\begin{abstract}
Many people are worried about how they will reach the toilet after a surgical procedure, or how they will use a bed pan if they have to remain in bed. Hospital staff deal with this concern every day. They are professional, empathetic and supportive, and you will find that they will support you in your bathroom habits without making you feel embarrassed. If you have concerns, ask the nursing staff when you arrive about what will happen when you need to go to the toilet.... It is best to get up and use the toilet (rather than a bedpan) if you can. Sitting on the toilet makes it easier to empty your bladder or bowel. However, if you can't move very much, there are a number of toileting aids available in hospitals. ${ }^{30}$
\end{abstract}

Because of their direct contact with dirt, in countries such as India, Yemen and Saudi Arabia, nurses are sometimes seen as belonging to a lower class. Nair and Healey write that the work of nurses in India, because of their involvement in cleaning and bathing sick and diseased bodies, is compared with the menial jobs of the 'lower' castes. ${ }^{31}$ But in Western countries as well, nurses are sometimes associated with dirty work. According to Olwig, Caribbean nurses who came to the UK after the Second World War faced double discrimination: as immigrants and as nurses doing the dirtiest jobs. ${ }^{32}$ But, as Robert McMurray argues, the dirtiness of nurses' work is also a 'potential source of pride, service and care' (p142). ${ }^{33}$ Furthermore, the position of nurses 
in most Middle Eastern countries has improved and gained some status more recently, as a nursing diploma can now deliver a ticket for a job in the USA and other Western countries. ${ }^{34}$

Jocalyn Lawler, herself a nurse and anthropologist, has called nursing a 'social entity' more than anything else. Looking back on her research among nurses regarding bodily work, she concludes in her preface: 'This research has left me with a very profound and new respect for nurses. I have become deeply impressed with the extent of their sensitivity to the experiences of their patients' (p2). ${ }^{35}$

\section{INDISPENSABLE CLEANERS}

Our overview of the actors involved in helping dependent patients to relieve themselves in hospitals or other care institutions would not be complete without briefly mentioning support workers like cleaners and 'wardboys'. Zaman, in his Bangladeshi hospital ethnography, describes wardboys and gatemen as low-ranked but indispensable workers in the hospital. ${ }^{13}$ As informal brokers they fill the gaps in care, communication and logistics between patients and their relatives on the one side and nurses and doctors on the other. ${ }^{13,36}$ Patients and their relatives pay them for their services. One of their services is helping a patient to the toilet if there is no relative around or assisting the patient while defecating in or next to the bed. We assume that informal workers in hospitals elsewhere in the region render the same service. It is also necessary, however, to point out that the cleaners of the Bangladeshi hospital particularly highlighted extreme resource constraints as a cause of the failure to maintain cleanliness in the hospitals. As one cleaner commented:

Hundreds of visitors come to the ward. They throw everything on the floor. We are the only ones on duty in the morning and in the evening. It is a huge task to sweep this big ward alone. We also cannot keep the toilet clean. Sometimes I find it difficult to enter into the toilet. I wash it once in the morning. But how is it possible to keep it clean? So many people use it throughout the day. Sometimes there is no water. For the last 15 days there has been no bleaching powder, soap, or Fenyle [an antiseptic solution]. I told the nurses and doctors, but I am still waiting for the materials. How can I do my job properly? (p134). ${ }^{13}$

\section{CONCLUDING REMARKS}

Reading through this collection of personal experiences and ethnographic observations surrounding defecation in hospitals and other institutions of care, one does not immediately think of aesthetics and sweet sentiments. Disgust and its suppression are the foremost emotions that seem to be at play in such situations. The professionals and relatives who assist patients in need of help while defecating are aware that they are invading the patient's privacy, when that privacy is normally most strictly observed. Their approach in such a situation requires exceptional tact and the control of negative sensory emotions, to reassure the patient that they have no other intention than to help. They 'have to find a balance between preserving their and others' dignity on the one hand, and intimacy on the other hand' (p207). ${ }^{37}$

Apart from their awareness that they are intruding into the patient's most intimate space of privacy, nurses and caregiving relatives also experience an intrusion of their own privacy, as they are forced to experience bodily intimacy with the patient. The encounter requires a delicate balancing act from both actors, in which mutual respect and personal integrity are at stake. ${ }^{38}$ The successful management of this combination of physical dirt, control of disgust and breach of privacy can take several paths, usually a tactful performance of neutrality: letting the hands do while the mind tries to be somewhere else.
But handling the dirty bodily substances of a sick person can also become a 'beautiful' thing, an act of love and positive emotion. 'Beautiful shit', if you like. Three instances come to mind. During an interactive lecture on dirt and defecation to an international group of students (in which both authors were involved), we noticed that one person was not taking part in the discussion and seemed very emotional to the point of crying. We asked her why she was crying and she explained that 3 months ago her husband had died after a long and painful sickness during which he had been bedridden. Throughout the period of his sickness, she had cared for him. Cleaning him, she said, had been her dearest act of showing him her love. The day's discussion about defecation had brought back these precious memories.

The second example is taken from Philip Roth's novel 'Patrimony' about Roth's relationship with his father. ${ }^{39}$ It is a moving story about his father's fight against a fatal brain tumour. Roth describes how he came closer to his father in the last months of his life, in which his father had to gradually surrender his charms and bravado. 'Patrimony' is what the father gives to his son when he dies.

In the novel, Roth constantly talks about things his father wants to give him. But this collection of utensils and other objects is not the heritage that Roth is referring to in the title of his autobiographic novel, no matter how symbolic they may be for passing on life. Roth does not use the word 'patrimony' until he finds his father in the bathroom, confused after he has let his stool run. Everything is covered with shit, the floor, the shower, the bath mat, his clothes spread across the floor, even the toothbrush. Roth reassures him, comforts him, cleans up the mess and helps him in the shower. The 'patrimony' is the intimacy between father and son which had slowly been lost over the course of a lifetime-growing up is growing distant-but which was made possible again when the son cleaned up his father's dirt in the face of impending death. Roth's description reminded Zaman of a similar experience with his own dying father:

Once I was changing the diaper and cleaning the private parts of my bedridden father. I asked if it was embarrassing for him that I was doing this. He smiled and told me, "Not at all, rather I think I have given you this precious opportunity to care for me."

Acknowledgements We thank the respondents in Bangladesh, and friends and colleagues who enthusiastically shared with us their experiences with defecation in various uneasy conditions.

Contributors Both authors are fully responsible for the text of this manuscript.

Funding The authors have not declared a specific grant for this research from any funding agency in the public, commercial or not-for-profit sectors.

Competing interests None declared.

Patient and public involvement Patients and/or the public were not involved in the design, or conduct, or reporting, or dissemination plans of this research.

Patient consent for publication Obtained.

Provenance and peer review Not commissioned; externally peer reviewed.

Data availability statement Data sharing not applicable as no data sets generated and/or analysed for this study. The essay is based on anthropological observations and the authors' personal experiences in Bangladesh, Ghana and the Netherlands and covers a wide variety of cultural and politicoeconomic conditions. It further draws on (scarce) scientific publications as well as on fictional sources.

Open access This is an open access article distributed in accordance with the Creative Commons Attribution Non Commercial (CC BY-NC 4.0) license, which permits others to distribute, remix, adapt, build upon this work non-commercially, and license their derivative works on different terms, provided the original work is 
properly cited, appropriate credit is given, any changes made indicated, and the use is non-commercial. See: http://creativecommons.org/licenses/by-nc/4.0/.

\section{ORCID iD}

Sjaak van der Geest http://orcid.org/0000-0002-9943-6415

\section{NOTES}

1. David Howes and Constance Classen (2013), Ways of Sensing: Understanding the Senses in Society (Oxford: Routledge).

2. Victoria Bates (2019), "Sensing Space and Making Place: The Hospital and Therapeutic Landscapes in Two Cancer Narratives," Medical Humanities 45, no. 1: 10-20.

3. Devon E Hinton, David Howes, and Laurence J Kirmayer (2008), "Toward a Medical Anthropology of Sensations: Definitions and Research Agenda," Transcultural Psychiatry 45, no. 2: 142-62.

4. Gerhard Nijhof (2018), Sickness Work: Personal: Reflections of a Sociologist (Singapore: Palgrave/Macmillan).

5. Carolyn Korsmeyer and Barry Smith (2004), "Visceral Values: Aural Kolnai on Disgust, " in On Disgust, by Aural Kolnai (Peru, Illinois: Carus Publishing Company), 1-25.

6. Paul Rozin and April E Fallon (1987), "A Perspective on Disgust," Psychological Review 94, no. 1: 23-41.

7. Paul Rozin, Jonathan Haidt, and Clark R. McCauley (2000), "Disgust," in Handbook of Emotions, ed. Michael Lewis, Jeannette M. Haviland-Jones, and Lisa Feldman Barrett (New York: Guilford), 637-53.

8.V Curtis and A Biran (2001), "Dirt, Disgust, and Disease. Is Hygiene in Our Genes?" Perspectives in Biology and Medicine 44, no. 1: 17-31.

9. Valerie Curtis (2013), Don't Look, Don't Touch, Don't Eat: The Science Behind Revulsion (Chicago/London: University of Chicago Press).

10. John L Esposito, "Intoxicants," Oxford Islamic Studies Online, www. oxfordislamicstudies.com

11. Mary Douglas (1966), Purity and Danger: An Analysis of Concepts of Pollution and Taboo (Harmondsworth: Penguin).

12. Sjaak van der Geest (2007) Author (2007).

13. Zaman, Shahaduz (2005) Author (2005).

14. Josiane Carine Tantchou (2016), Petits pas d'Ethnographe, Suivi de'Portrait d'Hôpital (Mémoire d'Habilitation, Université de Bordeaux).

15. The Guardian (August 8, 2004), "Patient Survey Says Hospital Toilets Dirtier," The Guardian, August 8, 2004, https://www.theguardian.com/society/2004/aug/08/ hospitals.nhs

16. Käthe Von Bose and Klinisch Rein (2017), Klinisch Rein. Zum Verhältnis von Sauberkeit, Macht und Arbeit im Krankenhaus (Bielefeld: Transcript).

17. Rachel Lea (2000), "The Performance of Control and the Control of Performance: Towards a Social Anthropology of Defecation" (PhD diss. (unpublished), Brunel University, London).

18. Julia Lawton (1998), "Contemporary Hospice Care: The Sequestration of the Unbounded Body and 'Dirty Dying'," Sociology of Health \& IIIness 20, no. 2: $121-43$.

19. Shahaduz Zaman (2013) Author (2008).

20. Alice Street (2009), "Failed Recipients: Extracting Blood in a Papua New Guinean Hospital," Body \& Society 15, no. 2: 193-215.

21. Hannah Brown (2012), "Hospital Domestics: Care Work in a Kenyan Hospital," Space \& Culture 15, no. 1: 18-31.

22. Benson Mulemi (2010), Coping with Cancer and Adversity. Hospital Ethnography in Kenya (Leiden: African Studies Centre).

23. Ly-yun Chang (2001), "Family at the Bedside: Strength of the Chinese Family or Weakness of Hospital Care?" Current Sociology 49, no. 3: 155-73.

24. Klaas W Van der Veen (1995), "Zelfbeschikking in Afhankelijkheid? De Ambiguïteit van Ouderenzorg in Nederland. [Self-Determination in Dependence: The Ambiguity of Elderly Care in the Netherlands]," in Ambivalentie/Ambiguïteit: Antropologische Notities [Ambivalence/Ambiguity: Anthropological Notes], ed. Sjaak van der Geest (Amsterdam: Het Spinhuis), 57-65.

25. Lori L Jervis (2001), "The Pollution of Incontinence and the Dirty Work of Caregiving in a U.S. Nursing Home," Medical Anthropology Quarterly 15, no. 1: 84-99.

26. Johannes Van Dijk (2018), "'Scheiße!' Darf Man Nicht Sagen. Stuhlgang als Pflegerische Herausforderung," Pflege: Demenz 46: 22-6.

27. Jacomine De Lange (1991), Zorgen voor Dementerende Ouderen [Caring for Dementing Older People], vol. 96 (Houten: Bohn Stafleu Van Loghum).

28. Christine Böhmig (2010), Ghanaian Nurses at a Crossroads. Managing Expectations on a Medical Ward (Leiden: African Studies Centre).

29. Jan AM Kerstens (2002), Basisverpleegkunde [Basic Nursing] (Houten: Bohn Stafleu van Loghum).
30. Better Health Channel (2018), "Going to the Toilet in Hospital," https://www. betterhealth.vic.gov.au/health/servicesandsupport/going-to-the-toilet-in-hospital? viewAsPdf=true

31. Sreelekha Nair and Madelaine Healey (2006), "A Profession on the Margins: Status Issues in Indian Nursing," Conference presentation, http://www.cwds.ac.in/wpcontent/uploads/2016/09/A-Profession-on-the-margins.pdf

32. Karen Fog Olwig (2018), "Female Immigration and the Ambivalence of Dirty Care Work: Caribbean Nurses in Imperial Britain," Ethnography 19, no. 1: 44-62.

33. Robert McMurray (2012), "Embracing Dirt in Nursing Matters," in Dirty Work: Concepts and Identities, ed. Ruth Simpson, Natasha Slutskaya, Patricia Lewis, and Heather Höpfl (London: Palgrave Macmillan), 126-42.

34. Philomina Thomas (2006), "The International Migration of Indian Nurses," Nursing Review 53, no. 4: 277-83. doi: 10.1111/j.1466-7657.2006.00494.x.

35. Jocalyn Lawler (2006), Behind the Screens: Nursing, Somology, and the Problem of the Body (Sydney: Sydney University Press).

36. Shahaduz Zaman and Sjaak van der Geest, 2020 Author and Author (n.d.).

37. Els Van Dongen (2001), "It Isn't Something to Yodel about, But It Exists! Faeces, Nurses, Social Relations and Status within a Mental Hospital, " Ageing \& Mental Health 5, no. 3: 205-15.

38. Harry Van der Bruggen (1991), Patiënt, Privaat en Privacy: De Stoelgang als Gezondheidswetenschappelijk Probleem [Patient, Privy and Privacy: Bowel Movement as a Health Science Problem] (Lochem: De Tijdstroom).

39. Philip Roth (1991), Patrimony (New York: Simon \& Schuster).

\section{BIBLIOGRAPHY}

Bates, Victoria. "Sensing Space and Making Place: The Hospital and Therapeutic Landscapes in Two Cancer Narratives." Medical Humanities 45, no. 1 (2019): 10-20.

Better Health Channel. "Going to the Toilet in Hospital." 2018. https://www. betterhealth.vic.gov.au/health/servicesandsupport/going-to-the-toilet-inhospital?viewAsPdf=true.

Böhmig, Christine. Ghanaian Nurses at a Crossroads. Managing Expectations on a Medical Ward. Leiden: African Studies Centre, 2010.

Brown, Hannah. "Hospital Domestics: Care Work in a Kenyan Hospital." Space \& Culture 15, no. 1 (2012): 18-31.

Chang, Ly-yun. "Family at the Bedside: Strength of the Chinese Family or Weakness of Hospital Care?" Current Sociology 49, no. 3 (2001): 155-73.

Curtis, Valerie, and Adam Biran. "Dirt, disgust, and disease. is hygiene in our genes?" Perspectives in Biology and Medicine 44, no. 1 (2001): 17-31.

Curtis, Valerie. Don't Look, Don't Touch, Don't Eat: The Science Behind Revulsion. Chicago/ London: University of Chicago Press, 2013.

De Lange, Jacomine. Zorgen voor Dementerende Ouderen [Caring for Dementing Older People], vol. 96. Houten: Bohn Stafleu Van Loghum, 1991.

Douglas, Mary. Purity and Danger: An Analysis of Concepts of Pollution and Taboo, vol. 1970. Harmondsworth: Penguin, 1966.

Esposito, John L. "Intoxicants." Oxford Islamic Studies Online. www.oxfordislamicstudies. com. Accessed June 19, 2019.

Hinton, Devon E, David Howes, and Laurence J Kirmayer. "Toward a Medical Anthropology of Sensations: Definitions and Research Agenda." Transcultural Psychiatry 45, no. 2 (2008): 142-62.

Howes, David, and Constance Classen. Ways of Sensing: Understanding the Senses in Society. Oxford: Routledge, 2013.

Jervis, Lori L. "The Pollution of Incontinence and the Dirty Work of Caregiving in a U.S. Nursing Home." Medical Anthropology Quarterly 15, no. 1 (2001): 84-99.

Kerstens, Jan AM. Basisverpleegkunde [Basic Nursing], vol. 207. Houten: Bohn Stafleu van Loghum, 2002.

Korsmeyer, Carolyn, and Barry Smith. "Visceral Values: Aural Kolnai on Disgust." In On Disgust, byAural Kolnai, 1-25. Peru, Illinois: Carus Publishing Company, 2004

Lawler, Jocalyn. Behind the Screens: Nursing, Somology, and the Problem of the Body. Sydney: Sydney University Press, 2006.

Lawton, Julia. "Contemporary Hospice Care: The Sequestration of the Unbounded Body and 'Dirty Dying'." Sociology of Health \& IIIness 20, no. 2 (1998): 121-43.

Lea, Rachel. "The Performance of Control and the Control of Performance: Towards a Social Anthropology of Defecation. "PhD diss. (unpublished), Brunel University, London, 2000.

McMurray, Robert. "Embracing Dirt in Nursing Matters." In Dirty Work: Concepts and Identities, edited byRuth Simpson, Natasha Slutskaya, Patricia Lewis, and Heather Höpfl, 126-42. London: Palgrave Macmillan, 2012.

Mulemi, Benson. Coping with Cancer and Adversity. Hospital Ethnography in Kenya. Leiden: African Studies Centre, 2010.

Nair, Sreelekha, and Madelaine Healey. "A Profession on the Margins: Status Issues in Indian Nursing. Conference presentation." Workshop "Women Migrating in India", New Delhi, 2006. http://www.cwds.ac.in/wp-content/uploads/2016/09/A-Professiononthe-margins.pdf. 
Nijhof, Gerhard. Sickness Work: Personal: Reflections of a Sociologist. Singapore: Palgrave/ Macmillan, 2018.

Olwig, Karen Fog. "Female Immigration and the Ambivalence of Dirty Care Work: Caribbean Nurses in Imperial Britain." Ethnography 19, no. 1 (2018): 44-62.

Roth, Philip. Patrimony. New York: Simon \& Schuster, 1991.

Rozin, Paul, and April E Fallon. "A Perspective on Disgust." Psychological Review 94, no. 1 (1987): 23-41.

Rozin, Paul, Jonathan Haidt, and Clark R. McCauley. "Disgust." In Handbook of Emotions, edited byMichael Lewis, M Jeannett Haviland-Jonese, and Lisa Feldman Barrett, 637-53. New York: Guilford, 2000.

Street, Alice. "Failed Recipients: Extracting Blood in a Papua New Guinean Hospital." Body \& Society 15, no. 2 (2009): 193-215.

Tantchou, Josiane Carine. Petits pas d'Ethnographe, Suivi de'Portrait d'Hôpital.Mémoire d'Habilitation, Université de Bordeaux, 2016.

The Guardian. "Patient Survey Says Hospital Toilets Dirtier." The Guardian, August 8, 2004. https://www.theguardian.com/society/2004/aug/08/hospitals.nhs.

Thomas, Philomina. "The International Migration of Indian Nurses." International Nursing Review 53, no. 4 (2006): 277-83.

Van der Bruggen, Harry. Patiënt, Privaat en Privacy: De Stoelgang als Gezondheidswetenschappelijk Probleem [Patient, Privy and Privacy: Bowel Movement as a Health Science Problem]. Lochem: De Tijdstroom, 1991. van der Geest, Sjaak. "The Social Life of Faeces: System in the Dirt." In Wildness and Sensation: An Anthropology of Sinister and Sensuous Realms, edited byvan Ginkel, Rob, and Strating, Alex, 381-97. Amsterdam: Het Spinhuis, 2007.

Van der Veen, Klaas W. "Zelfbeschikking in Afhankelijkheid? De Ambiguïteit van Ouderenzorg in Nederland. [Self-Determination in Dependence: The Ambiguity of Elderly Care in the Netherlands]." In Ambivalentie/Ambiguiteit: Antropologische Notities [Ambivalence/Ambiguity: Anthropological Notes], edited bySjaak van der Geest, 57-65. Amsterdam: Het Spinhuis, 1995.

Van Dijk, Johannes. "'Scheiße!' Darf Man Nicht Sagen. Stuhlgang als Pflegerische Herausforderung." Demenz Pflege 46 (2018): 22-6.

Van Dongen, Els. "It Isn't Something to Yodel about, But It Exists! Faeces, Nurses, Social Relations and Status within a Mental Hospital." Aging \& Mental Health 5, no. 3 (2001): 205-15.

Von Bose, Käthe, and Klinisch Rein. Zum Verhältnis von Sauberkeit, Macht und Arbeit im Krankenhaus, 155-9. Bielefeld: Transcript, 2017.

Zaman,Shahaduz. Broken Limbs, Broken Lives: Ethnography of a Hospital Ward in Bangladesh. Amsterdam: Het Spinhuis, 2005.

Zaman, Shahaduz. "Silent saviours: family members in a Bangladeshi Hospital." Anthropology \& Medicine 20, no. 3 (2013): 278-87.

Zaman, Shahaduz, and Sjaak van der Geest. "Brokers on the ward: ward boys, cleaners, and Gatemen in a Bangladeshi Hospital." Asian journal of social science 48, no. 1-2 (2020): 92-114. 